Japan. J. Med. Sci. Biol., 40, 109-117, 1987.

\title{
DETECTION OF ANTIBODIES TO SENDAI VIRUS IN MOUSE SERA BY ENZYME-LINKED IMMUNOSORBENT ASSAY (ELISA)
}

\author{
Eiko SUZUKI, Akira NOGUCHI and Hisao TAKEDA1 \\ Department of Veterinary Science and 1Virology and Rickettsiology, National \\ Institute of Health, Kamiosaki, Shinagawa-ku, Tokyo 141
}

(Received December 26, 1986. Accepted October 6, 1987)

SUMMARY: Enzyme-linked immunosorbent assay (ELISA) for diagnosis of Sendai virus infection in mice was evaluated. A large-scale survey of infected mice showed that ELISA is approximately 100 times more sensitive than the hemagglutination-inhibition or complement-fixation test. Although a few SPF mice showed false-positive reactions at a serum dilution of $1: 40$, further dilution to 1:80 eliminated the non-specific reaction. It was shown that ELISA is a highly satisfactory method for examination of Sendai virus infection in mice.

\section{INTRODUCTION}

Natural infection with Sendai virus occurs in a variety of laboratory rodents (1-4). Sendai virus is the agent of the most important respiratory disease in mice. Hemagglutination-inhibition (HI) and complement-fixation (CF) tests have been used for diagnosis of Sendai virus infection since its finding (5). Enzyme-linked immunosorbent assay (ELISA) is being widely used for diagnosis of numerous infectious diseases for its reliability and high sensitivity $(6,7)$. The choise of the enzyme and its substrate is critical for the assay.

The present study evaluates the ELISA method using horse radish peroxidase (HRP) and 2,2'-azinobis(3-ethylbenzothiazolin-6-sulfonic acid) diammonium salt (ABTS) as its substrate (8) for detection of serum antibody of mice to Sendai virus.

鈴木映子·野口 章 (国立子防衛生研究所獣疫部)

武田久雄 (国立予防衛生研究所ウイルス・リケッチャ部) 


\section{MATERIALS AND METHODS}

Viral antigen: Sendai virus, strain M-73, was prepared by the method described (9). Briefly, the egg-grown virus was used for infection of mice. The virus concentrated by centrifugation at $20,000 \mathrm{rpm}$ for $1 \mathrm{hr}$ was layered onto a 20 $60 \%(\mathrm{w} / \mathrm{v})$ linear sucrose gradient, which was centrifuged at 25,000 rpm for $3 \mathrm{hr}$. The virus banded between 29 and $38 \%$ (w/w) sucrose was collected, sonicated and used for ELISA. Uninfected allantoic fluid treated in the same manner was used as a control antigen. The protein content was determined by the method of Lowry et al (10).

Mouse sera: 4-week-old female mice (Specific pathogen-free: SPF) of C57BL/6 (Shizuoka Laboratory Animal Center, SLAC, Shizuoka) were used. Sendai virusinfected 4-week-old female mice of ICR strain (from SLAC) were used for contact infection as described (9). Healthy mice $(\mathrm{C} 57 \mathrm{BL} / 6)$ were housed in a cage together with two mice (ICR) infected by nasal instillation with $5 \times 106.0 \mathrm{ID}_{50}$ of Sendai virus 3 day earlier. Three mice $(\mathrm{C} 57 \mathrm{BL} / 6)$ were killed every 2 days and examined for serum antibody to Sendai virus.

SPF mice of BALB/c, GPC, DD and C57BL/6 were housed in the same room. C57BL/6 mice infected naturally with Sendai virus were accidentally introduced into the room and the viral infection seemed to spread among the mice in the room. The infection was monitored for 3 months, and all 37 mice in the room were killed for detection of antibody to Sendai virus.

Forty-seven sera from SPF mice of different strains free from Sendai virus were also employed in the present study as negative controls.

To investigate a regression line between ELISA titers and ELISA values, 45 sera from mice infected with Sendai virus at an early stage of infection (day 6 to 12) were also used.

Procedures of ELISA: A modification of the ELISA method of Valler et al. (11) was used. From the results of preliminary experiments on the conditions affecting ELISA, the following procedures and conditions were employed. Each well of polystyrene flat-bottomed microtiter plates (Ts-Flat, Toyoshima Co., Tokyo) was coated with $50 \mu \mathrm{l}$ of virus antigen suspended in carbonate-bicarbonate buffer ( $\mathrm{pH}$ 9.6) at a concentration of $4 \mu \mathrm{g}$ protein per ml overnight at $4 \mathrm{C}$ and washed four times with $100 \mu$ l of phosphate-buffered saline (PBS, $\mathrm{pH} 7.4$ ) containing $0.05 \%$ (w/v) Tween 20 (PBS-Tween). All the subsequent steps were done in a volume of 50 $\mu l$ per well at room temperature, except the substrate reaction in $200 \mu l$. To avoid non-specific adsorption to the wells, buffer (PBS-Tween) containing $0.1 \%$ bovine serum albumin (BSA-buffer) was added to the antigen-coated well for $30 \mathrm{~min}$. After removal of the BSA-buffer, a serum sample diluted in BSA-buffer was added to the wells and allowed to stand for $1 \mathrm{hr}$. After washing, HRP-conjugated goat anti-mouse immunoglobulin G (heavy- and light-chain specific: Cappel Laboratories, Cochraville, PA) diluted 1:1,000 was added and kept standing for 1 $\mathrm{hr}$. After washing, a 200- $\mu$ l volume of freshly prepared substrate $(0.3 \mathrm{mg}$ per $\mathrm{ml}$ of ABTS, Nakarai Chemicals, Tokyo, plus $70 \mu \mathrm{l}$ of hydrogen peroxide per $100 \mathrm{ml}$ of 
citrate-phosphate buffer, $\mathrm{pH}$ 5.0) was added. The reaction giving an emerald green color was allowed to proceed for $45 \mathrm{~min}$ in the light before addition of $10 \mu \mathrm{l}$ of $1.25 \%$ sodium fluoride (Sigma Chemicals, St. Louis, MO) as a stopper. Absorbance at 415 $\mathrm{nm}(A 415)$ was measured. Positive and negative control sera were always included and the difference larger than 0.20 in $A 415$ was considered positive. The ELISA titer, therefore, was the reciprocals of the highest serum dilution giving an $A 415$ larger than 0.20 .

HI and CF test: The HI and CF tests were performed by the methods of Sever (12) and Suzuki et al. (1), respectively.

\section{RESULTS}

\section{Conditions for ELISA for the Detection of Antibodies to Sendai Virus}

Our aim was focused first at controlling the reaction-conditions for ELISA for serodiagnosis of Sendai virus infection. Although the adsorption of antigen to wells arrived at a peak in $30 \mathrm{~min}$ at $4 \mathrm{C} \mathrm{(13),} \mathrm{overnight} \mathrm{adsorption} \mathrm{at} 4 \mathrm{C}$ was adopted for routine use. To determine the optimal concentration of the viral antigen, the wells were coated with various concentrations of the antigen. They were washed and allowed to react with serum from infected mice and the specific reactions were determined by reading $A 415$. From the standard curve, it was evident that ELISA value reached a plateau of approx. 1.6 OD at an antigen concentration of $6 \mathrm{\mu g} / \mathrm{ml}$ (data not shown). This showed that an antigen concentration of $3 \mu \mathrm{g} / \mathrm{ml}$ would give the highest antibody titer, but for routine assay, we selected an antigen concentration of $4 \mu \mathrm{g} / \mathrm{ml}(0.2 \mu \mathrm{g} / \mathrm{well})$. ELISA with different concentrations of the conjugate showed that the 1,000-fold dilution would be suitable for use in the test (data not shown).

Further experiments were performed to seek the optimal temperature by which the serum, conjugate and substrate reactions are induced. From a series of experiments, we arrived at the following conclusion: all the reactions should be done at $25 \mathrm{C}$.

To know occurrence false-positive reactions, sera from 47 mice free from Sendai virus were examined with uninfected allantoic fluid (negative control antigen) by ELISA. Although two (4.3\%) were found to react at a serum dilution of 1:40, an additional twofold dilution to 1:80 eliminated the non-specific reaction. 
The reciprocal of the highest serum dilution with $A 415$ larger than 0.20 was used as the antibody titer. Value smaller than 0.20 at a serum dilution of $1: 80$ were considered negative.

\section{Parallel Titrations of Serum Antibody by ELISA, HI and CF Tests}

ELISA was evaluated in the following two ways: One was the time course of antibody rise in C57BL/6 mice infected by contact with infected mice through nasal instillation. Thirty-three mice 4-week-old were used and three mice were randomly killed every 2 days for antibody titration by ELISA, HI and CF. As can be seen in Fig. 1, the antibody was first detected on day 6 by ELISA and all mice became antibody-positive two days later. HI and CF tests, however, failed to detect antibody on day 6 after infection, indicating a 2-day delay in seroconversion by these tests. Mice were found to possess the highest ELISA titers of 10,240 from 16 to 22 days post infection.

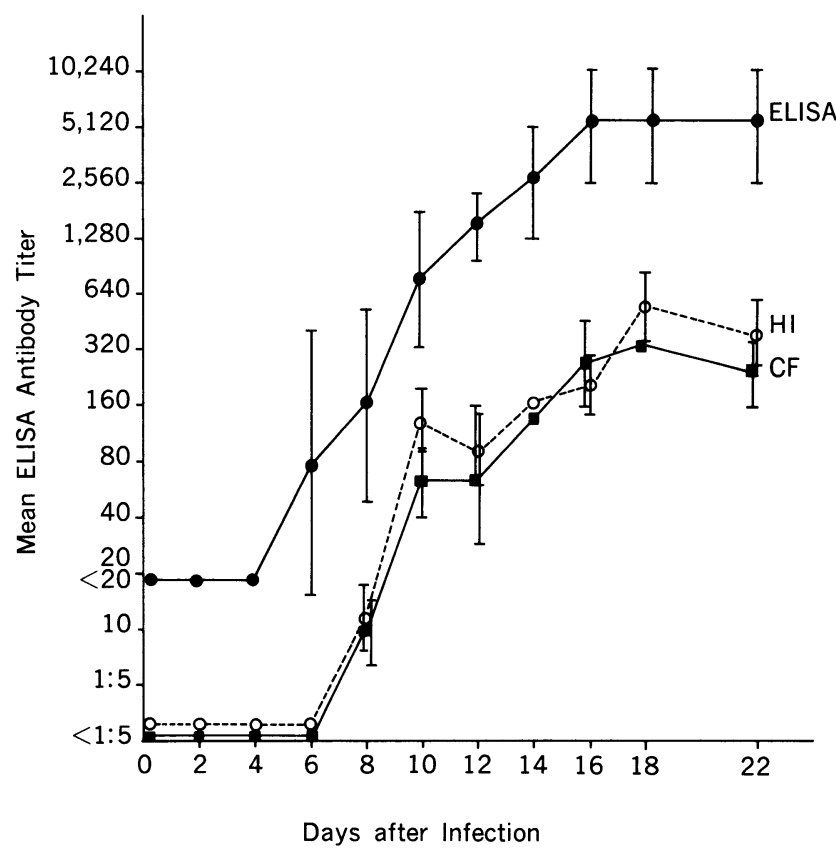

Fig. 1. The time course of antibody response determined by ELISA, HI and CF in sera of C57BL/6 mice infected by contact with Sendai virusinfected mice. Results are expressed as the mean ELISA antibody titers ( ) with the standard deviation (vertical lines). HI ( $-\cdots$ and CF titers ( $\square$ ) are expressed in the same manner. 
Table I. Titration of sera from mice naturally infected with Sendai virus1)

\begin{tabular}{|c|c|c|c|c|}
\hline \multirow{2}{*}{$\begin{array}{l}\text { Mouse } \\
\text { No. }\end{array}$} & \multirow{2}{*}{ Strain } & \multicolumn{3}{|c|}{ Titer to Sendai virus by } \\
\hline & & ELISA & $\mathrm{HI}$ & $\mathrm{CF}$ \\
\hline 1 & ICR & $1: 160$ & -2) & - \\
\hline 2 & & 40 & - & - \\
\hline 3 & & 160 & - & - \\
\hline 4 & & $-3)$ & - & - \\
\hline 5 & & - & - & - \\
\hline 6 & & 320 & - & - \\
\hline 7 & & 320 & $1: 10$ & - \\
\hline 8 & & 320 & 10 & $1: 20$ \\
\hline 9 & & 320 & 20 & 10 \\
\hline 10 & & 320 & 10 & 10 \\
\hline 11 & & 640 & 20 & 10 \\
\hline 12 & & 320 & 20 & 5 \\
\hline 13 & & 320 & 20 & 10 \\
\hline 14 & & 640 & 40 & 20 \\
\hline 15 & & 1.280 & 40 & 10 \\
\hline 16 & & 320 & 10 & 10 \\
\hline 17 & & 2,560 & 20 & 20 \\
\hline 18 & & 320 & 20 & 10 \\
\hline 19 & & 1,280 & 20 & 10 \\
\hline 20 & GPC & 1,280 & 20 & 40 \\
\hline 21 & & 1,280 & 20 & 40 \\
\hline $\begin{array}{l}22 \\
23\end{array}$ & & $\begin{array}{l}2,560 \\
5,120\end{array}$ & $\begin{array}{l}40 \\
40\end{array}$ & $\begin{array}{l}40 \\
40\end{array}$ \\
\hline 24 & & 40 & $\begin{array}{l}40 \\
10\end{array}$ & $\begin{array}{l}40 \\
20\end{array}$ \\
\hline 25 & $\mathrm{C} 57 \mathrm{BL} / 6$ & 1,280 & 20 & 80 \\
\hline 26 & & 640 & 20 & 80 \\
\hline 27 & & - & - & - \\
\hline 28 & & $\bar{z}$ & - & - \\
\hline 30 & & - & - & - \\
\hline 31 & & & - & _- \\
\hline 32 & BALB/c & 320 & - & - \\
\hline 33 & & 640 & - & 10 \\
\hline 34 & & $0 x$ & - & - \\
\hline 35 & & - & - & $=$ \\
\hline 36 & DD & - & - & - \\
\hline 37 & & - & - & - \\
\hline
\end{tabular}

1) The infection of mice is explained in Materials and Methods.

2) Negative at 1:40 serum dilution by ELISA.

3) Negative at 1:5 serum dilutions by $\mathrm{HI}$ and CF.

The antibody titer was defined as the reciprocal of the highest serum dilution giving positive reaction in ELISA, complete inhibition in $\mathrm{HI}$ and positive reaction (no or less than $25 \%$ hemolysis) in CF. 
Secondly, 37 SPF mice comprising BALB/c, GPC, DD and C57BL/6 strains were kept in the room where accidental infection with Sendai virus occurred. The infection was monitored for about 3 months after the possible introduction of the virus and all 37 mice were killed to examine for the antibody to Sendai virus by the three methods (Table I). Many mice were infected with Sendai virus and the antibody titer was markedly higher in ELISA than in HI or CF test. The antibodies with titers of 40 to 320 by ELISA were not detectable by HI or CF, showing again that ELISA is more sensitive than the others.

\section{The Relationship between the ELISA Value and Antibody Titer}

The antibody titers obtained by ELISA, HI and CF tests were compared to see if a linear relationship is observed among them. As shown in Table II, the

Table II. Comparison of ELISA to HI and CF titers to Sendai virus of mouse sera

\begin{tabular}{|c|c|c|c|c|c|c|c|c|c|c|}
\hline \multirow{2}{*}{$\begin{array}{l}\text { Anti- } \\
\text { body }\end{array}$} & \multirow{2}{*}{$\begin{array}{l}\text { Number } \\
\text { of sera ex- } \\
\text { amined }\end{array}$} & \multicolumn{9}{|c|}{ Number of sera with ELISA titer of } \\
\hline & & 10,240 & 5,120 & 2,560 & 1,280 & 640 & 320 & 160 & 80 & 0 \\
\hline \multicolumn{11}{|l|}{ HI-titer } \\
\hline 640 & 2 & & 2 & & & & & & & \\
\hline 320 & 5 & 2 & 2 & 1 & & & & & & \\
\hline 160 & 8 & & 2 & 3 & 2 & & 1 & & & \\
\hline 80 & 3 & & & & 3 & & & & & \\
\hline 40 & 4 & & 1 & 1 & 1 & 1 & & & & \\
\hline 20 & 11 & & & 1 & 4 & 2 & 4 & & & \\
\hline 10 & 7 & & & & & 1 & 5 & & & 1 \\
\hline 5 & 0 & & & & & & & & & 1 \\
\hline 0 & 30 & & & & & & 3 & 2 & 1 & 24 \\
\hline \multicolumn{11}{|l|}{ CF-titer } \\
\hline 320 & 6 & & 5 & 1 & & & & & & \\
\hline 160 & 6 & 1 & 1 & 3 & 1 & & & & & \\
\hline 80 & 2 & & & 1 & 1 & & & & & \\
\hline 40 & 7 & & 1 & 1 & 5 & & & & & \\
\hline 20 & 6 & & & 1 & 1 & 2 & 2 & & & \\
\hline 10 & 11 & & & & 2 & 2 & 4 & 3 & & \\
\hline 5 & 2 & & & & & & 1 & & & 1 \\
\hline 0 & 30 & & & & & & 3 & 2 & 1 & 24 \\
\hline
\end{tabular}


ELISA titers tended to increase in parallel with the HI and CF titers. The ELISA titers were 100 -fold higher than the $\mathrm{HI}$ and CF titers. To obtain a regression line, serum samples were grouped according to the levels of ELISA titers. When ELISA values obtained at a single dilution of 1:80 of sera from mice were plotted against the antibody titers, a linear regression curve was obtained (Fig. 2). The linear regression curve of $A 415$ of 0.24 to 1.4 indicates that an ELISA value at a single serum dilution of $1: 80$ can be converted to the antibody titer.

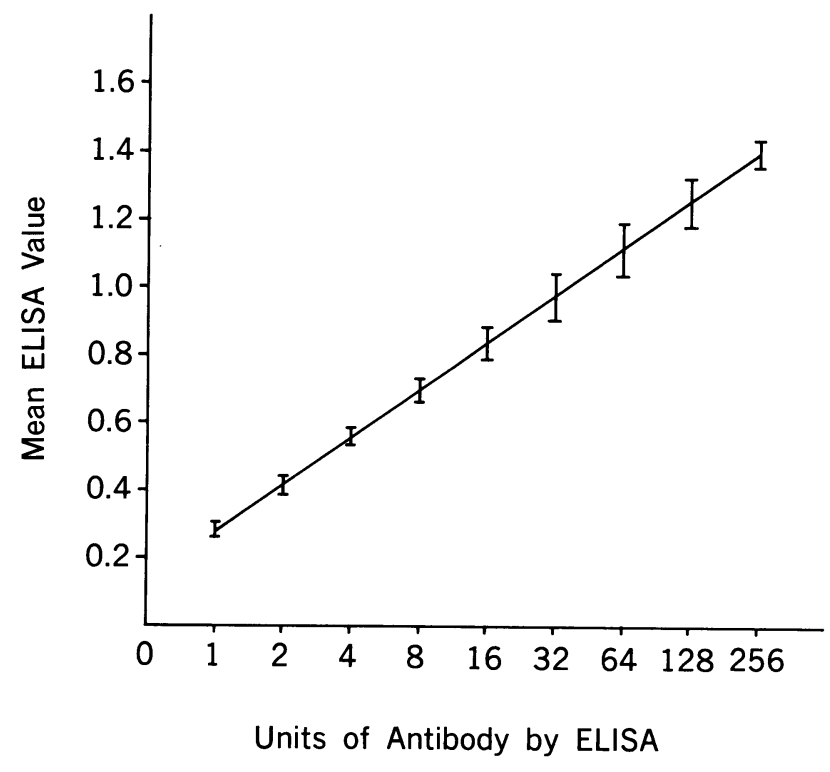

Fig. 2. The relationship between ELISA value and antibody units. Results are expressed as the mean ELISA value with the standard error (vertical line) versus the antibody units and a regression line is depicted. The regression equation is $\mathrm{y}=0.0891 \mathrm{X}+0.03$, and the correlation coefficient $(r)$ is 1.00 . 


\section{DISCUSSION}

ELISA using HRP-conjugate and substrate-ABTS is useful for detection of antibody to Sendai virus. Conditions for ELISA, such as the concentration of the coating antigen $(4 \mathrm{\mu g} / \mathrm{ml})$, reaction temperature $(25 \mathrm{C}$ or room temperature for 1 $\mathrm{hr}$ ), the concentration of enzyme-conjugated antiglobulin (1:1,000 dilution) and the dilution of the test serum, were determined. Alkaline phosphatase (AP) and its substrate, $p$-nitrophenyl phosphate (NP), have widely been used at $37 \mathrm{C} \mathrm{(14)}$ and satisfactory in many assays, whereas the present study revealed that the viral antigen was unstable at $37 \mathrm{C}$. For this reason, HRP and ABTS, which give an emerald green color in the light at $25 \mathrm{C}$, were used instead of AP and NP because of unstable antigenicity of Sendai virus. Comparison of the results obtained in ELISA with 70 sera with those in $\mathrm{HI}$ and CF led us to the conclusion that ELISA is very sensitive. Moreover, ELISA is very useful for detection of such low levels of antibody that can not be detected by $\mathrm{HI}$ or $\mathrm{CF}$, detecting seroconversion at early stages of Sendai virus infection. False-positive reactions (4.3\%) observed at a 1:40 serum dilution could be eliminated by an additional single twofold dilution to 1:80 of the test serum. Simple and rapid procedures, in addition to its high sensitivity, make ELISA more useful than HI and CF for serodiagnosis of Sendai virus infection in mice.

\section{REFERENCES}

1. Suzuki, E., Matsubara, J., Saito, M., Muto, T., Nakagawa, M. and Imaizumi, K. (1982): Japan. J. Med. Sci. Biol., 35, 249-254.

2. Paker, J. C. and Reynolds, R. K. (1968): Amer. J. Epidemiol., 88, 112-125.

3. Appell, L. H., Kovatch, R. M., Reddecliff, J. M. and Gerone, P. J. (1971): Amer. J. Vet. Res., 32, 1835-1841.

4. Robinson, J. W. E., Cureton, R. J. R. and Hearth, R. B. (1968): J. Med. Microbiol., 1, 89-95.

5. Paker, J. C., Whiteman, M. D. and Richter, C. B. (1978): Infect. Immun., 19, 123-130.

6. Parker, J. C., Obeirne, A. J. and Collins, M. J. (1979): J. Clin. Microbiol., 9, 444-447.

7. Ertl, H. C. J., Gerlich, W. and Koszinowski, J. H. (1979): J. Immunol., Meth., 28, 163-176.

8. O'sullivan, M. J. and Marks, V. (1981): Meth. Enzymol., 73, 147-166.

9. Suzuki, E., Kinoshita, K., Muto, T., Nakagawa, M. and Imaizumi, K. (1982): Japan. J. Med. Sci. Biol., 35, 81-85. 
10. Lowry, O. H., Rosenbrough, N. J., Farr, A. L. and Randall, R. J. (1951): J. Biol. Chem., 193, 265-275.

11. Voller, A., Bidwell, D. and Barlett, A. (1976): In N. Rose and H. Priedman [eds.], p.506-512. Manual of clinical immunology American Society for Microbiology, Washington, D. C.

12. Sever, J. L. (1962): J. Immunol., 88, 320-329.

13. Bidwell, D. E., Bartlett, A. and Voller, A. (1977): J. Infect. Dis., 136, S274278.

14. Gilman, S. C. and Docherty, J. J. (1977): J. Infect. Dis., 136, S286-293. 